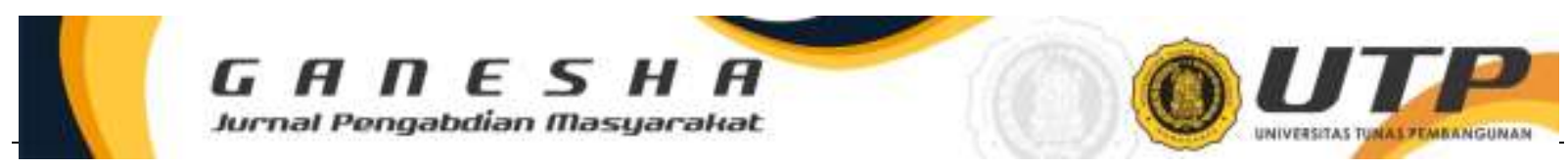

\title{
OPTIMALISASI BUMDes MELALUI PENGOLAHAN SAMPAH RUMAH TANGGA DESA PANDEYAN
}

\author{
Ratna Kumala Setyaningrum*1, Yudi Karisma Sari², Herywansyah ${ }^{3}$ \\ ${ }^{1,2,3}$ Universitas Tunas Pembangunan Surakarta \\ *e-mail: ratnakumala05@gmail.com
}

\begin{abstract}
Abstrak
Badan Usaha Milik Desa (BUMDes) merupakan usaha yang dikelola oleh desa sesuai dengan kebutuhan dan potensi desa dengan harapan dapat meningkatkan pendapatan masyarakat dan desa. Tujuan pengabdian masyarakat ini adalah mengoptimalisasikan usaha BUMDes desa Pandeyan melalui pengolahan limbah rumah tangga. Sasaran kegiatan adalah (1) Petugas lapangan bagian dari keanggotaan BUMDes Pandeyan terdiri dari 8 orang. (2) Warga RT 02 RW 09 Welar Pandeyan Ngemplak Boyolali. Kegiatan dilaksanakan dalam 6 langkah, yaitu (1) sosialisasi dan koodinasi dengan pihak BUMDes dan warga terpilih. (2) Pengadaan lahan pengolahan sampah, alat dan bahan. (3) Pemisahan sampah organik dan anorganik. (4) Pelatihan pembuatan pupuk. (5) Eduksi warga untuk memisahkan sampah organik dan anorganik. (6) Pengelolaan sampah menjadi pupuk dilanjutkan dengan target pemasaran. Hasil pengolahan limbah rumah tangga ini berupa : pupuk, sampah yang dikelola bank sampah dan sampah yang diteruskan ke TPA.
\end{abstract}

Kata kunci: BUM Des, organik, kompos

\begin{abstract}
Village-Owned Enterprises (VOE) are businesses run by the village to meet the needs and potential of the community, with the goal of increasing community and village income. The goal of this community service is to improve the VOE Pandeyan village's business by processing household organic waste. The targets of the activity are (1) Field officers who are part of the VOE Pandeyan membership consisting of 8 people, (2) Residents of Neighbourhood 02 Hamlet 09 Welar Pandeyan Ngemplak Boyolali. The activity was carried out in six steps: (1) socialization and coordination with VOEs and selected residents; (2) Acquisition of land for waste processing, as well as tools and materials, (3) Organic and inorganic waste separation, (4) Composting training, (5) residents' socialization about the importance of sorting organic and inorganic waste, (6) Organic waste composting is followed by target marketing. The result of this household waste management produces fertilizer, waste managed by a waste bank, and waste dumbed to the landfills.
\end{abstract}

Keywords: VOEs,morganic, compost

\section{PENDAHULUAN}

Undang-Undang Nomor 6 Tahun 2014 tentang Desa, pada Bab X menyatakan bahwa Desa dapat mendirikan Badan Usaha Milik Desa yang disebut BUMDesa. Pemerintah Desa dapat mendirikan Badan Usaha Milik Desa sesuai dengan kebutuhan dan potensi desa dengan harapan dapat meningkatkan pendapatan masyarakat dan desa. Sebagai tindak lanjut dari pelaksanaan pendirian BUM Desa, maka berdasarkan Pasal 136 Peraturan Pemerintah Nomor 43 Tahun 2014 Tentang Peraturan Pelaksanaan UU Nomor 6 tentang Desa sebagaimana telah diubah dengan Peraturan Pemerintah Nomor 47 Tahun 2015 tentang Perubahan Atas Peraturan Pemerintah Nomor 43 Tahun 2014 tentang Peraturan Pelaksanaan Undang-Undang Nomor 6 Tahun 2014 tentang Desa, serta berdasarkan Peraturan Menteri Desa Pembangunan Daerah Tertinggal dan Transmigrasi Republik Indonesia nomor 4 tahun 2015 tentang Pendirian, Pengurusan dan Pengelolaan dan Pembubaran Badan Usaha Milik Desa.

BUMDesa merupakan instrumen pendayagunaan ekonomi lokal dengan berbagai ragam jenis potensi. Pendayagunaan potensi ini terutama bertujuan untuk peningkatan kesejahteran ekonomi warga desa melalui pengembangan usaha ekonomi mereka. Disamping itu, 
keberadaan BUM Desa juga memberikan sumbangan bagi peningkatan sumber pendapatan asli desa yang memungkinkan desa mampu melaksanakan pembangunan dan peningkatan kesejahteraan rakyat secara optimal. Upaya sistematis sangatlah diperlukan, hal ini untuk mendorong organisasi ini agar mampu mengelola aset ekonomi strategis di desa sekaligus mengembangkan jaringan ekonomi demi meningkatkan daya saing ekonomi perdesaan.

BUMDesa pada dasarnya merupakan bentuk konsolidasi atau penguatan terhadap lembaga-lembaga ekonomi desa. Beberapa agenda yang bisa dilakukan untuk mencapai tujuan didirikannya BUMDesa ini antara lain: 1) Pengembangan kemampuan SDM sehingga mampu memberikan nilai tambah dalam pengelolaan aset ekonomi desa; 2) Mengintegrasikan produkproduk ekonomi perdesaan sehingga memiliki posisi nilai tawar baik dalam jaringan pasar; 3) Mewujudkan skala ekonomi kompetitif terhadap usaha ekonomi yang dikembangkan; 4) Menguatkan kelembagaan ekonomi desa; 5) Mengembangkan unsur pendukung seperti perkreditan mikro, informasi pasar, dukungan teknologi dan manajemen, prasarana ekonomi dan jaringan komunikasi maupun dukungan pembinaan dan regulasi.

Sesuai analisis di atas, Desa Pandeyang merupakan salah satu desa di Kecamatan Ngemplak Kabupaten Boyolali yang saat ini membentuk BUMDesa guna meningkatkan ekonomi lokas berbasis kemandirian. Saat ini, permasalahan yang ada di Desa Pandeyan berkaitan dengan keberadaan sampah. Pengelolaan sampah rumah tangga diserahkan kepada pihak swasta dimana sampah ini dikumpulkan di TPS. Pengelolaan sampah ini setiap rumah tangga dipungut biaya Rp. 25.000/bulan. Pemerintah Desa Pandeyan melihat keberadaan sampah ini sebagai sumber masalah dan juga sebagai salah satu sektor ekonomi bila tepat pengelolaannya. Hingga sekarang belum ada tempat pengelolaan sampah yang dikelola secara khusus untuk bisa menjadi salah satu peluang usaha. Dengan jumlah penduduk 3.083, usaha pengelolaan sampah ini bisa menjadi peluang usaha desa.

Tim Pengabdian UTP Surakarta, melihat bahwa pengetahuan tentang pengolahan sampah ini dapat menjadi peluang usaha desa, yaitu memberikan peluang kerja bagi masyarakat, meringankan pengeluaran rumah tangga dan yang lebih penting hasil pengolahan sampah ini bisa dimanfaatkan untuk dijual.

\section{METODE}

Kegiatan Pegabdian Masyarakat ini dilaksanakan di Desa Pandeyang Kecamatan Ngemplak di bawah pengawasan BUMDesa. Sasaran kegiatan ini ada 2, yaitu: (1) Petugas lapangan bagian dari keanggotaan BUMDes Pandeyan terdiri dari 8 orang. (2) Warga RT 02 RW 09 Welar Pandeyan Ngemplak Boyolali. Kegiatan ini dilaksanakan pada skala kecil megingat di desa Pandeyan baru pertaa kali dilakukan. Sasaran pertama, yaitu pertugas yang masuk dalam keanggotaan BUMDes sebagai pelaksana lapangan dalam proses pengolahan sampah, sedangkan sasaran kedua adalah warga, sebagai pensuplay sampah. Langkah-langkah pengabdian masyarakat ini adalah sebagai berikut: (1) sosialisasi dan koodinasi dengan pihak BUMDes dan warga terpilih. (2) Pengadaan lahan pengolahan sampah, alat dan bahan. (3) Pemisahan sampah organik dan anorganik. (4) Pelatihan pembuatan pupuk. (5) Eduksi warga untuk memisahkan sampah organik dan anorganik. (6) Pengelolaan sampah organik menjadi pupuk dilanjutkan dengan target pemasaran. 


\section{HASIL DAN PEMBAHASAN}

\section{Sosialisasi dan koodinasi dengan pihak BUM Des dan warga terpilih}

Kegiatan pertama adalah sosialisasi sekaligus koordinasi dengan pengurus BUMDes terkait pelaksanaan kegiatan pengelolaan sampah warga. Tujuan dibentuknya unit pengelola sampah warga ini adalah untuk meringankan beban warga terhadap pungutan kebersihan. Selain itu diharapkan dalam pelaksanaannya nanti bisa membuka peluang kerja bagi warga yang masih belum memiliki pekerjaan tetap.

Langkah awal sosialisasi ini dilakukan dalam 2 (dua) sesi, yaitu sesi 1 (satu) berupa penjelasan program kerja BUMDes serta perencanaan ke depan terkait keberadaan usaha pengelolaan sampah warga. Sesi 1 ini diberikan oleh perangkat desa dibantu oleh Tim Pengabdian UTP. Sesi 2 (dua) mengenai tata laksana pengelolaan sampah warga mulai dari awal sosialisasi warga terkait pemisahan sampah, pengumpulan, pemilahan kembali sampah, pengolahan sampah, hasil pengolahan sampah, dan pemasaran.

Pengadaan alat dan bahan

Tahap kedua berupa pengadaan alat dan bahan serta tempat. Pada kegiatan ini perencanaan masih dilakukan dalam skala kecil menyesuaikan dengan anggaran yang tersedia. Tempat pengolahan sampah sudah disediakan oleh pemerintah Desa Pandeyan melalui BUM des. Alat yang diperlukan berupa (1) tempat sampah sederhana yang dibagikan kepada warga untuk memisahkan sampah organik dan non organik. Pengadaan tempat sampah ini dikelola olah warga sendiri dengan memanfaatkan berbagai tempat bekas seperti ember bekas cat atau ember bekas lainnya. Kemudian dicat untuk membedakan tempat sampah organik dan anorganik. (2) tempat sampah guna pemprosesan sampah, (3) alat pencacah sampah, sekop, sapu, alat garuk, (4) bahan berupa sampah organik, larutan microba, air dan kayu.

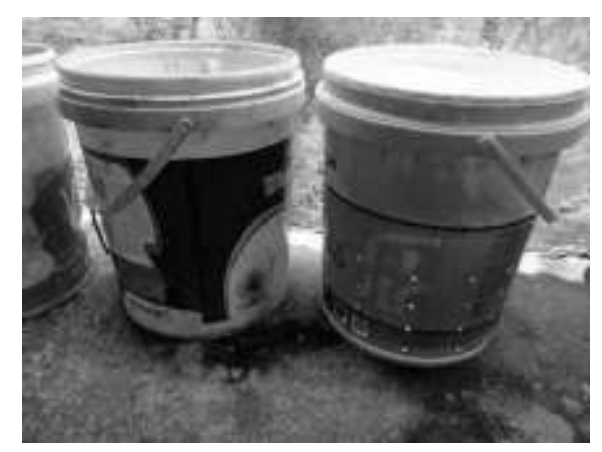

Gambar 1. Tempat sampah sederhana dari bahan bekas cat

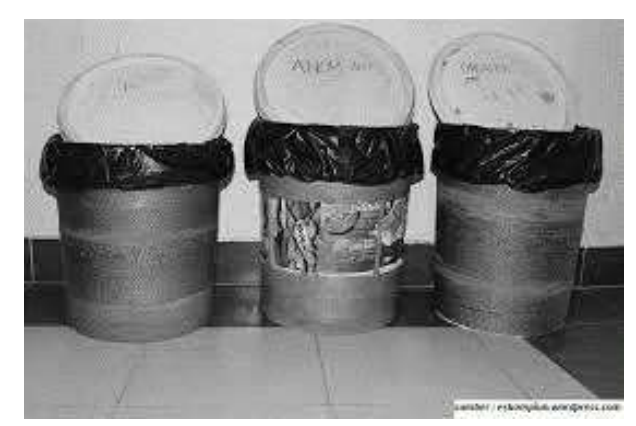

Gambar 2. Hasil modifikasi tempat bekas menjadi tempat sampah 


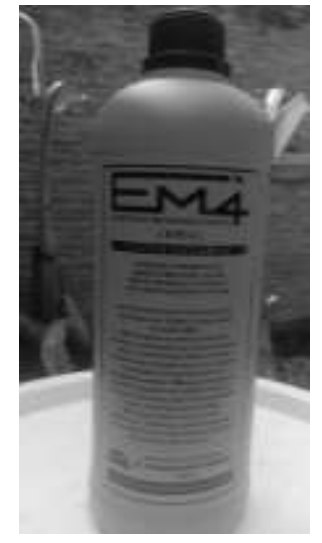

Gambar 3. Cairan EM4

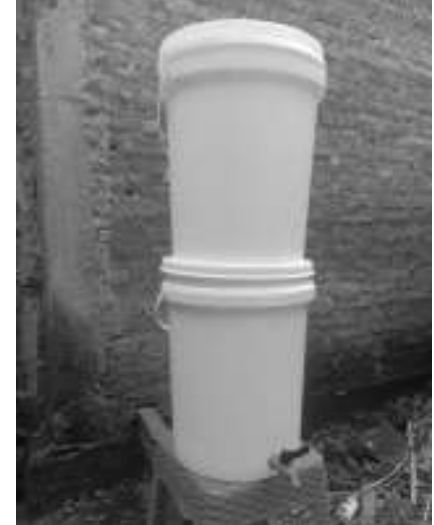

Gambar 4. Ember Pengolahan Sampah

\section{Pelatihan pembuatan kompos}

Usaha pengelolaan sampah ini melibatkan peran warga sebagai pensuplai bahan dasar. Sosialisasi yang dilakukan pada warga berupa edukasi terhadap jenis-jenis sampah (organik dan organik) sehingga warga bisa memisahkan sampah tersebut sesuai dengan jenisnya pada tempat sampah terpisah yang telah disediakan desa. Sampah limbah rumah tangga dipisahkan menjadi 3 (tiga) bagian, yaitu sampah untuk bahan pupuk kompos, sampah untuk bank sampah dan sampah yang tidak dapat diolah.

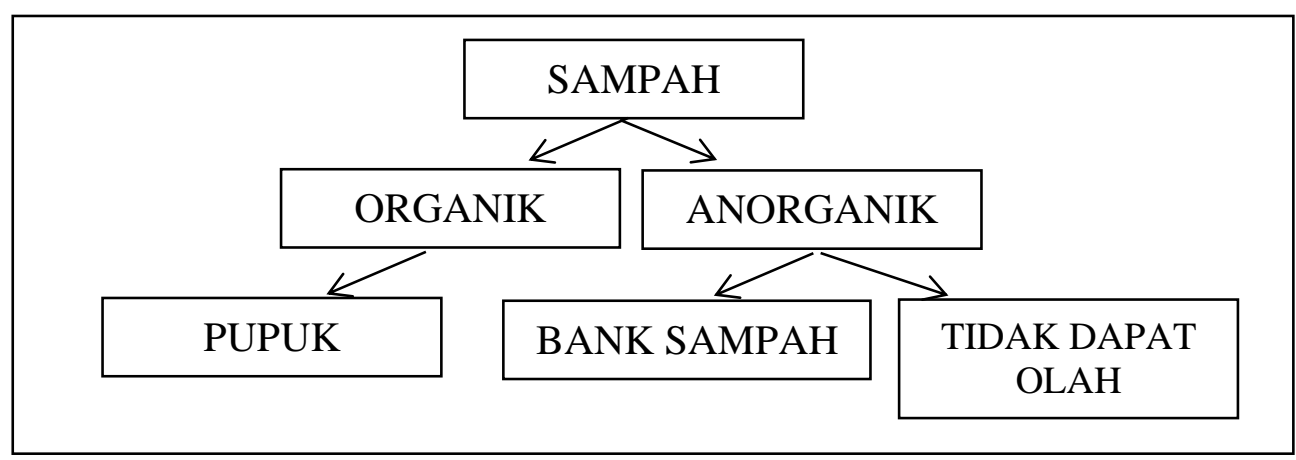

Gambar 3. Pengelompokan Sampah

Pemisahan sampah yang dimulai dari masing-masing rumah tangga ini, akan mempermudah petugas. Selanjutnya hasil dari sampah yang terkupul akan dimanfaatkan masing-maisng bidnag kerja usaha. Bidang pengolahan sampah organik dan bidang bank sampah untuk anorganik. Untuk sampah yang tidak dapat diolah akan diserahkan ke TPA.

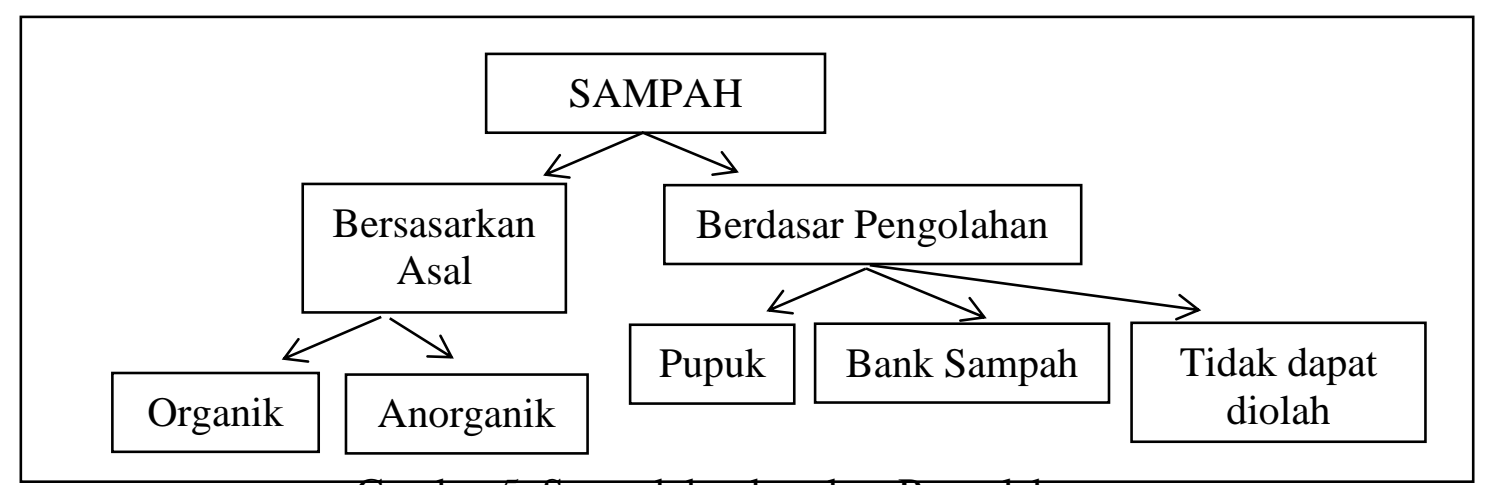

Gambar 5. Sampah berdasarkan Pengolahannya 
Tahap selanjutnya adalah pemilahan kembali sampah organik dan anorganik oleh pelaksana BUMDes. Sampah organik yang telah terkumpul diberi cairan yang mengandung microba (EM-4). Proses dari sampah hingga menjadi pupuk membutuhkan waktu sekitar dua minggu. Selama waktu itu, sampah terus diaduk untuk memastikan semua tercampur. Cairan yang dihasilkan dari pupuk ini akan menjadi starter mikrobia yang dapat digunakan pada proses pengolahan selanjutnya.

\section{Hasil kegiatan pengolahan sampah}

Hasil pengolahan sampah ini berupa pupuk kering dan pupuk cair, sampah daur ulang yang dikelola oleh Bank sampah dan sampah yang diserahkan ke petugas untuk dibuang di TPA. Sedangkan hasil pengolahan sampah organik dibagi 3 (tiga), yaitu : sampah kering biasa disebut dengan media, magot (belatung) dan pupuk cair. Sampah organik yang telah berproses dengan cairan microba berwarna coklat kehitaman masih mengandung air, sehingga sebelum masuk proses pembungkusan perlu dikeringkan terlebih dahulu. Magot yang diperoleh dapat dimanfaatkan untuk pakan lele dan pupuk cair bisa dikemas untuk dipasarkan ke warga.

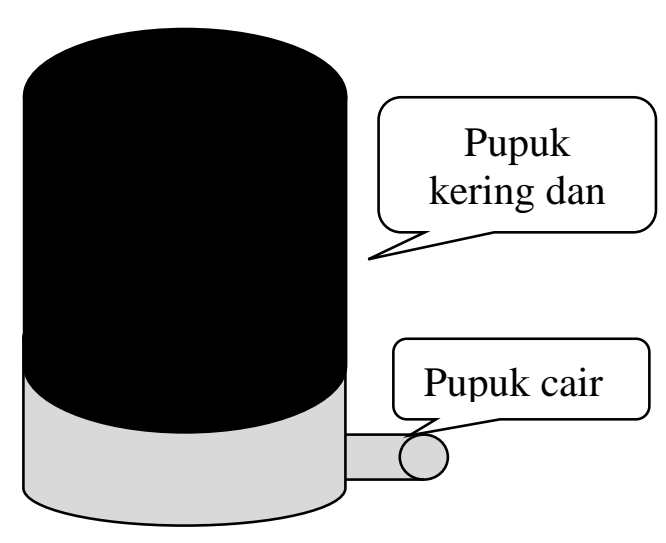

Gambar 6. Ilustasi Hasil Sampah Organik

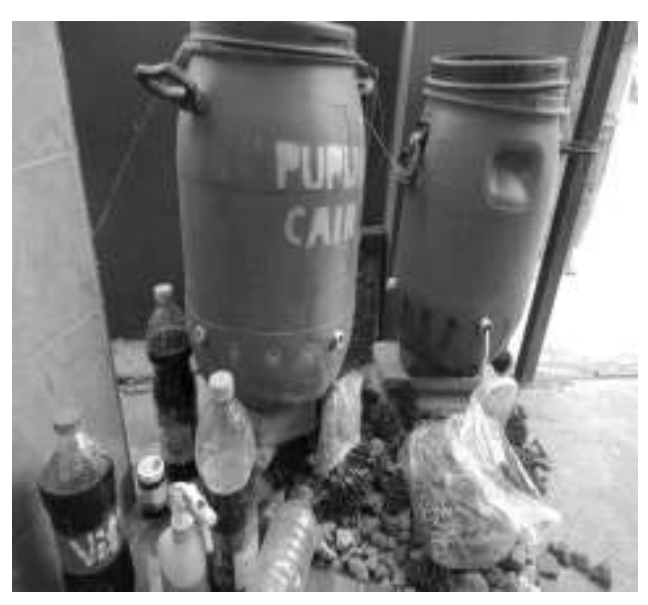

Gambar 7. Hasil Pengolahan Sambah

Pupuk yang dihasilkan tergantung dari suplai bahan dasar sampah dari warga. Oleh karena itu apabila BUMDes berhasil menggiatkan semua warga desa Pandeyan untuk mengumpulkan sampah organik, tentu hasil yang didapat dapat menjadi peluang usaha desa. Selain itu, dengan berkurangnya sampah organik, pemanfaatan bahan daur ulang oleh bank sampah dan sisa sampah yang akan dikirim ke TPA akan berkurang (Tempat Pembuangan Sampah) berkurang. Tentu hal ini sebagai upaya untuk meminimalisasi pencemaran lingkungan serta mengubah sampah menjadi sesuatu yang bermanfaat.

\section{KESIMPULAN}

BUMDes merupakan upaya pemerintah dalam memajukan desa. Melalui BUMDes diharapkan dapat membantu desa meningkatkan pendapatan sesuai dengan potensi yang dimiliki desa. Pemerintah Desa Pandeyan bekerjasama dengan tim Pengabdian UTP dan BUM Des melakukan kegiatan pengolahan sampah rumah tangga menjadi peluang usaha yang dapat memberikan pemasukan bagi desa maupun warga. Kegiatan ini dilakukan dalam skala kecil sebagai bentuk pelatihan. Dengan jumlah penduduk sekitar 3.083 pemerintah desa Pandeyan optimis usaha pengelolaan limbah organik rumah tangga ini akan mampu meningkatkan perekonomian masyarakat dan desa. 


\section{UCAPAN TERIMA KASIH}

Kegiatan ini terlaksana berkat bantuan dari berbagai pihak, oleh karena itu pada kesempatan ini, kami ucapkan terima kasih yang sebesar-besarnya kepada :

1. Pemerintah Desa Pandeyan

2. Tim BUM Des Pandeyan

3. Tim Pengabdian UTP Surakarta

4. Warga RT 02 RW 09 Welar Pandeyan Ngemplak Boyolal

\section{DAFTAR PUSTAKA}

DRPMP UTP Surakarta. 2018. Format Penyusunan Proposal Pengabdian Kepada Masyarakat. LPPM UTP. Surakarta.

Dyah R. I, Eva B. Margunani. 2015. Pengolahan limbah Organik Sampah Pasar menjadi Kompos. ABDIMAS Vol. 19 No. 1 